\title{
Asymptomatic bacteriuria in schoolchildren in Newcastle upon Tyne
}

\author{
NEWCASTLE ASYMPTOMATIC BACTERIURIA RESEARCH GROUP† \\ From the General Hospital and the Health Department, City and County of Newcastle upon Tyne
}

\begin{abstract}
Newcastle Asymptomatic Bacteriuria Research Group (1975). Archives of Disease in Childhood, 50, 90. Asymptomatic bacteriuria in schoolchildren in Newcastle upon Tyne. A screening survey for asymptomatic bacteriuria (ASB) in 13464 schoolgirls aged 4 to 18 years in Newcastle upon Tyne showed an overall prevalence of $1.9 \%$. In girls aged 4 to 6 years it was $1 \cdot 4 \%$, in girls aged 7 to 11 years it was $2 \cdot 5 \%$, and in girls aged 12 to 18 years it was $1.6 \%$, a statistically significant rise and fall. Renal scarring was found in 39 (15\%) of 254 girls with ASB. Neither the prevalence nor the severity of renal scarring increased with age. There was no association between ASB and social class. Of the 254 girls with ASB, 24\% had no symptoms. Infections with Klebsiella were more frequently associated with renal scarring than infections with Esch. coli.

The prevalence of ASB in 1595 boys aged 5 to 18 years was low, $0.2 \%$.

Ureteric reflux was present in $15 \%$ of girls without renal scarring and in $46 \%$ of those with renal scarring $(P<0 \cdot 001)$. Renal scarring also showed a significant association with duplication, hydroureter, or single saccules in the bladder. The greater the severity of scarring the more frequently was reflux present.

This study gave no evidence that asymptomatic bacteriuria leads to progressive renal damage during childhood. It therefore does not support the recommendation for prescriptive screening of schoolchildren, but emphasizes the need for prospective studies of the natural history of ASB.
\end{abstract}

The importance of undiagnosed bacteriuria as a factor associated with the development of chronic renal disease, though suggested by many authors, has not been established with certainty. The study conducted by Kunin, Zacha, and Paquin (1962) in Virginia, U.S.A., has shown that children, like adults, may have significant bacteriuria in the absence of symptoms which lead their parents to seek medical advice. In this American survey the overall incidence of asymptomatic bacteriuria (ASB) in 5132 girls aged 5 to 24 years was found to be

Received 28 June 1974.

*This report should be referred to as the Newcastle Asymptomatic Bacteriuria Investigation-First Report (1975). Analyses were prepared by A. R. R. Cain, J. A. Furness, J. B. Selkon, and W. Simpson.

†Microbiologists: Drs. J. B. Selkon (Co-ordinator), H. R. Ingham, G. E. Rich. Nephrologist: Dr. P. R. Uldall. Paediatricians: Drs. A. R. R. Cain, G. Davison (Chairman), T. C. Noble. Radiologists: Drs. S. M. Hale, W. Simpson. Statisticians: Mr. J. A. Furness, Mr. R. A. Macnay. Urologists: Prof. J. Swinney, Mr. W. K. Yeates. Medical Officers of Health: Prof. R. C. M. Pearson, Drs. W. B. Shaw, D. L. Wilson.
$1 \cdot 1 \%$ but there were differences between white and Negro girls. When these racial groups were separated and then subdivided according to age the numbers were insufficient to indicate if the prevalence of ASB varied at different stages of childhood.

Three studies have reported on the prevalence of ASB in schoolgirls in the U.K. but all have been confined to children aged 13 years and under (Meadow, White, and Johnston, 1969; Asscher et al., 1973; Savage et al., 1973). It was therefore decided to undertake a survey on the prevalence of ASB among schoolchildren in Newcastle upon Tyne to determine whether there was an increase with age in the incidence of either ASB or of acquired renal radiographic abnormalities. This report presents the results of this survey in schoolchildren aged 4 to 18 years, the clinical and bacteriological findings, and the prevalence of radiographic abnormalities. Further reports will present the results of studies on the natural history and the effectiveness of treating ASB. 


\section{Survey population and methods}

(a) Administrative procedures and the population studied. The City of Newcastle upon Tyne has a population of 221390 , nearly all being British born. The School Health Service is organized around 8 school clinics each staffed by a School Medical Officer and School Nurse. Each clinic area contains a representative section of private and council housing. Though many families from social classes I and II live outside the city, this is offset by children who come into the city to attend 'private' (i.e. non Local Authority) schools. The clinic areas were visited sequentially, with preliminary meetings with head teachers and letters to parents explaining that a child could be excluded from the survey if the parent so desired. From October 1968 to July 1972 all the schools in 4 of the 8 clinic areas were visited. The sole criterion for inclusion in the survey was that the child should attend school within the boundaries of the City of Newcastle. During the period 1968 to 1972 the average number of children attending school was 44000 , including 5847 children at private schools. At the 46 schools in which screening was carried out there were 13751 girls and 11550 boys on the register, including 2359 girls at 5 private schools.

(b) Screening procedure. Screening was carried out in a mobile clinic-laboratory previously described by Asscher et al. (1973). It was staffed by a nurse and a laboratory technician employed for school terms only. Each child on entry was checked against a copy of the school register, given a study number and then had a midstream specimen of urine (MSU) collected in the clinic area. Initially both sexes were screened. Boys were instructed to pass an MSU directly into a universal container. A nurse assisted the younger boys. Girls sat on a raised lavatory seat and an MSU was collected by the nurse interposing a sterile disposable aluminium foil dish held in a circular ring with a handle. The urine was poured into a universal container and passed to the laboratory section. Preliminary washing and drying of the perineum was undertaken only in girls aged over 11 years. The specimen was inoculated onto both blood agar and a MacConkey agar plate, using a fused iridiumplatinum loop* calibrated to deliver $0.001 \mathrm{ml}$ urine. The number of leucocytes $/ \mathrm{mm}^{3}$ in the urine was enumerated in a counting chamber. The plates were incubated aerobically overnight at $37{ }^{\circ} \mathrm{C}$ in the mobile laboratory and the numbers of colonies counted.

It was originally planned to test two further specimens obtained on consecutive days if the first specimen of urine yielded growth of more than $10^{4}$ organisms $/ \mathrm{ml}$. However, in the first year of the study it became apparent that when coagulase-negative staphylococci were present in a viable count of between $10^{4}$ and $10^{5}$ organisms $/ \mathrm{ml}$ neither of the subsequent specimens yielded more than $10^{4} / \mathrm{ml}$. Secondly, in only one of 19 patients in whom coagulase-negative staphylococci were present in a count of more than $10^{5}$ organisms $/ \mathrm{ml}$ was this result confirmed by the two further specimens. It was therefore decided

^Johnson-Matthey Limited, Hatton Garden, L.ondon. to repeat the screening tests on girls who yielded coagulase-negative staphylococci, only if the viable count was more than $10^{5} / \mathrm{ml}$. For all other bacteria, present in counts of more than $10^{4} / \mathrm{ml}$ in the first specimen, the two further specimens of urine were obtained. For these further specimens preliminary perineal toilet was undertaken in all girls. Those children who had $10^{5}$ or more organisms per $\mathrm{ml}$ in two or more of the three specimens of urine examined were regarded as having significant bacteriuria. This was irrespective of the genus of the organism isolated.

The organisms isolated on culture were brought to the hospital laboratory for full species identification by means of the standard biochemical tests (Cowan and Steel, 1965) and antibiotic sensitivity tests using the disc diffusion method. The organisms identified as Esch. coli were sent to Dr. B. Rowe, Director of the Salmonella Reference Laboratory, Central Public Health Laboratory, Colindale, who had kindly agreed to type them serologically.

The child's serum, which was subsequently collected at hospital, was tested for agglutinating antibodies to one of the isolates of Esch. coli obtained during the screening survey and one obtained at hospital, using the method described by Percival, Brumfitt, and Louvois (1964).

(c) Examination at hospital. An explanatory visit was made to the parents of each child found to have bacteriuria by one of the screening team and the relevant general practitioner was sent a letter reporting the screening test results and inquiring: (1) whether he was aware of any previous clinical or laboratory evidence of a urinary tract infection and whether the child had previously been referred to hospital for investigation of urinary tract disease; (2) whether he agreed to the child being referred to hospital. Children previously referred to hospital and diagnosed there as having a urinary tract infection were excluded from the category of asymptomatic bacteriuria and were referred back to their physician.

The children attended hospital usually with one of their parents. The interval between the ASB being detected on screening and the children finally attending hospital was on average 5 weeks, range 1 to 12 weeks. At hospital the child and parent were seen by a consultant and he completed a questionnaire and examination proforma. Specific inquiry was made into health in infancy, appetite, thirst, abdominal or loin pain, vomiting, unexplained febrile illness, diurnal and nocturnal frequency of micturition, age of achieving urinary continence, and present nocturnal or diurnal incontinence, pain on micturition, urgency, and haematuria; and if any medication had been received since the initial screening test. Routine examination included measurement of height and weight, note of any abdominal tenderness or palpable enlargement of kidneys or bladder, inspection of genitalia and measurement of blood pressure. An MSU was collected and arrangements made to obtain 5 further specimens at weekly intervals. The specimens were sent to the laboratory within an hour of being collected. The leucocytes were 
enumerated in a counting chamber and the viable bacteria were counted using the surface plate method described by Miles, Misra, and Irwin (1938) on blood agar and MacConkey agar plates. The organisms were identified and drug sensitivity tests were done as described above. Arrangements were also made at this visit for the patient to have an intravenous urogram (IVU) and micturating cystogram (MCG) during this 6-week period. At the time of the IVU blood was collected for blood urea and serum antibodies to the infecting organism. When the cystogram was being done, a catheter specimen of urine was collected for bacteriological examination as described above, with the addition of a Gram-stained film of the deposit and anaerobic culture.

(d) Radiology. Of the 254 girls referred for radiological investigation, each had an IVU and all but 2 had an MCG. When possible both examinations were done at the same attendance, the MCG preceding the IVU. If there was reflux to the kidney during the MCG the IVU was deferred to avoid confusion between excreted and refluxed contrast medium.

For the MCG, the bladder was filled with $15 \%$ Hypaque by infusion with the patient supine on the $x$-ray table. Using image intensification, the bladder was screened intermittently during filling and a single spot film taken with the bladder distended. When the patient experienced a desire to void the catheter was removed and she then micturated. During micturition the bladder and urethra were screened in the anteroposterior position and at least one spot film was taken. The following features were noted in every patient: the onset of micturition (normal, delayed or with urgency), the volume at which the desire to void appeared, the appearance of the bladder wall, the presence or absence of reflux and its grade (Table I) and timing.

For the IVU the dose of contrast medium was adjusted to the weight of the child. For girls weighing less than $45.5 \mathrm{~kg}, 20-40 \mathrm{ml}$ of $45 \%$ Hypaque were used, and for girls over this weight Conray 420 in a dose of $40 \mathrm{ml}$ was given. Three films were taken-a control, a full-size view of the abdomen at 12 minutes after injection, and a

TABLE I

Method of grading ureteric reflux and renal scarring

\begin{tabular}{|c|c|}
\hline \multicolumn{2}{|l|}{ Reflux } \\
\hline Grade 1 & Into pelvic or lumbar ureter only \\
\hline Grade 2 & Into renal pelvis but producing no distension \\
\hline Grade 3 & $\begin{array}{l}\text { Into renal pelvis producing distension of collecting } \\
\text { system or ureter }\end{array}$ \\
\hline Grade 4 & $\begin{array}{l}\text { Into renal pelvis with continuous distension of } \\
\text { collecting system and ureter }\end{array}$ \\
\hline \multicolumn{2}{|c|}{$\begin{array}{l}\text { Scarring } \\
\text { Each kidney was divided into upper, middle, and lower zones and a } \\
\text { score for each of } 0-3 \text { was given according to the severity of scarring. } \\
\text { Total scores were used for grading: }\end{array}$} \\
\hline $\begin{array}{l}\text { Mild } \\
\text { Moderate } \\
\text { Severe }\end{array}$ & $\begin{array}{l}=\text { total score } 1-3 \\
=\text { total score } 4-6 \\
=\text { total score } 7-9\end{array}$ \\
\hline
\end{tabular}

single tomogram of the kidneys immediately after the 12-minute film. In order to limit the dosage of radiation, only one repeat film was permitted for each patient. In every patient the following features were noted: the lengths of the kidneys, the presence or absence and grade (Table I) of kidney scarring, the presence or absence of hydronephrosis or duplication, and whether or not any other abnormalities were present.

(e) Classification and clinical management. A child was diagnosed as having renal involvement if she had (i) evidence of renal scarring or hydronephrosis on IVU, or (ii) excessive pyuria defined as more than 50 leucocytes $/ \mathrm{mm}^{3}$ in each of the 6 midstream specimens of urine collected at the hospital, or (iii) a clinical history suggesting active pyelonephritis. These children were treated as considered appropriate by the clinician involved.

Those who were not classified as having renal involvement were allocated at random, using sealed envelopes, to one of two treatment groups. One group was to receive antibacterial chemotherapy for 2 years. The other was to remain untreated unless on follow-up, a change in the IVU, or the development of symptoms made this necessary. Both groups were then followed up at the same frequency. The progress of all the children will form the basis of subsequent reports.

\section{Results}

Examination of boys. During the first 6 months of the survey both sexes were tested. In all, 1595 boys were screened of whom 279 were aged 5 to 7 years, 576 were 8 to 11 years, and 740 were 12 to 18 years. Of the 1595 boys, $3(0 \cdot 2 \%)-95 \%$ confidence limits being $0.4 \%-0.00 \%$-were found to have significant bacteriuria, that is $10^{5}$ or more organisms per $\mathrm{ml}$ in each of three specimens of urine. In view of this low prevalence of ASB in boys it was not considered worthwhile to screen any more of them in order to detect candidates for the prospective study of the natural history of this condition.

Of the 3 boys found to have significant bacteriuria, one aged 9 years was found to have left pelviureteric hydronephrosis with gross renal scarring of the left kidney; one aged 11 years had bilateral hydronephrosis due to impacted faeces; the third, aged 14 years, had a normal IVU and micturating cystogram.

\section{Examination of girls.}

Omissions from the survey. Of the 13751 girls who were on the registers of the schools visited, 287 $(2 \cdot 09 \%)$ were not tested when the screening unit was at the school (Table II). It was possible that, if they had included a large proportion of children with ASB, their omission could have seriously affected our estimate of the prevalence of this 
TABLE II

Prevalence of asymptomatic bacteriuria related to age of schoolgirls screened in Newcastle upon Tyne 1968 to 1972

\begin{tabular}{|c|c|c|c|c|c|c|c|}
\hline \multirow[t]{2}{*}{$\begin{array}{c}\text { Age } \\
\text { (year) }\end{array}$} & \multirow[t]{2}{*}{$\begin{array}{c}\text { Total girls on } \\
\text { school register } \\
\text { (no.) }\end{array}$} & \multirow[t]{2}{*}{$\begin{array}{l}\text { Girls not } \\
\text { tested } \\
\text { (no.) }\end{array}$} & \multicolumn{2}{|c|}{ Girls screened } & \multicolumn{2}{|c|}{$\begin{array}{l}\text { Asymptomatic bacteriuria } \\
\text { present }\end{array}$} & \multirow{2}{*}{$\begin{array}{c}\text { Bacteriuria } \\
\text { present but } \\
\text { previously known } \\
\text { (no.) }\end{array}$} \\
\hline & & & (no.) & $(\%)$ & (no.) & $(\%)$ & \\
\hline $\begin{array}{l}4 \\
5 \\
6\end{array}$ & $\begin{array}{ll} & 282 \\
1 & 048 \\
1 & 110\end{array}$ & $\begin{array}{r}4 \\
26 \\
12\end{array}$ & $\begin{array}{ll} & 278 \\
1 & 022 \\
1 & 098\end{array}$ & $\begin{array}{l}98 \cdot 6 \\
97 \cdot 5 \\
98 \cdot 9\end{array}$ & $\begin{array}{r}3 \\
13 \\
17\end{array}$ & $\begin{array}{l}1 \cdot 08 \\
1 \cdot 27 \\
1 \cdot 55\end{array}$ & $\begin{array}{l}0 \\
0 \\
2\end{array}$ \\
\hline $\begin{array}{r}7 \\
8 \\
9 \\
10 \\
11\end{array}$ & $\begin{array}{ll}1 & 113 \\
1 & 128 \\
1 & 033 \\
1 & 066 \\
1 & 112\end{array}$ & $\begin{array}{l}17 \\
14 \\
17 \\
14 \\
18\end{array}$ & $\begin{array}{ll}1 & 096 \\
1 & 114 \\
1 & 016 \\
1 & 052 \\
1 & 094\end{array}$ & $\begin{array}{l}98 \cdot 5 \\
98 \cdot 8 \\
98 \cdot 3 \\
98 \cdot 7 \\
98 \cdot 4\end{array}$ & $\begin{array}{l}28 \\
28 \\
26 \\
28 \\
23\end{array}$ & $\begin{array}{l}2 \cdot 55 \\
2 \cdot 51 \\
2 \cdot 56 \\
2 \cdot 66 \\
2 \cdot 10\end{array}$ & $\begin{array}{l}0 \\
2 \\
3 \\
3 \\
0\end{array}$ \\
\hline $\begin{array}{l}12 \\
13 \\
14 \\
15 \\
16 \\
17 \\
18\end{array}$ & $\begin{array}{r}1396 \\
1341 \\
1268 \\
852 \\
544 \\
347 \\
111\end{array}$ & $\begin{array}{r}34 \\
21 \\
23 \\
21 \\
34 \\
23 \\
9\end{array}$ & $\begin{array}{r}1362 \\
1320 \\
1245 \\
831 \\
510 \\
324 \\
102\end{array}$ & $\begin{array}{l}97 \cdot 6 \\
98 \cdot 4 \\
98 \cdot 2 \\
97 \cdot 5 \\
93 \cdot 8 \\
93 \cdot 4 \\
91 \cdot 9\end{array}$ & $\begin{array}{r}22 \\
22 \\
17 \\
16 \\
7 \\
5 \\
1\end{array}$ & $\begin{array}{l}1 \cdot 62 \\
1 \cdot 67 \\
1 \cdot 37 \\
1 \cdot 93 \\
1 \cdot 37 \\
1 \cdot 54 \\
0 \cdot 98\end{array}$ & $\begin{array}{l}1 \\
0 \\
1 \\
0 \\
0 \\
0 \\
0 \\
0\end{array}$ \\
\hline Total & 13751 & 287 & 13464 & $97 \cdot 9$ & 256 & $1 \cdot 90$ & 12 \\
\hline
\end{tabular}

condition. The reasons for their omission were therefore examined in detail and are given in Table III. The main reasons for failing to examine these 287 girls were (a) that 105 , mainly girls over 12 years of age, were absent from school during the 2-week period the screening team was at the school, and (b) that the parents of 118 others refused permission for the investigation, 35 of them because they believed that their daughters were already receiving medical treatment for urinary tract disease.

The possibility that this population contained an excess of children with ASB was studied in 3 ways. The first 50 of these 287 children were visited by a nurse at their home and the parents were asked to collect a clean specimen of urine and inoculate a dipslide (Mackey and Sandys, 1965). 47 of the 50 co-operated, and $2(4.3 \%)$ of them were finally confirmed to have ASB. The second approach was to obtain information on the 35 children who were stated to have been under treatment at the time; of these, 28 had been referred to hospital because of symptoms of urinary tract infection. In 4 of them this diagnosis was not confirmed. In the remaining 24, a urinary tract infection was confirmed and 4 were found to have pyelonephritis. However, all these 24 children had been referred to hospital because they had symptoms of urinary tract disease and thus they did not come within our definition of ASB. Thirdly, information was obtained on the 20 'absent' children who were known to be in hospital

TABLE III

Reason for failing to obtain specimens of urine from 287 schoolgirls in the screening survey

\begin{tabular}{|c|c|c|c|c|c|c|}
\hline \multirow{3}{*}{$\begin{array}{l}\text { Age group } \\
\quad \text { (year) }\end{array}$} & \multirow{3}{*}{$\begin{array}{l}\text { Total girls not } \\
\text { screened } \\
\text { (no.) }\end{array}$} & \multicolumn{5}{|c|}{ Reason for not being examined } \\
\hline & & \multirow[b]{2}{*}{$\begin{array}{c}\text { Child refused } \\
\text { to co-operate } \\
\text { (no.) }\end{array}$} & \multirow{2}{*}{$\begin{array}{l}\text { Absent from } \\
\text { school } \\
\text { (no.) }\end{array}$} & \multicolumn{2}{|c|}{ Parents refusal } & \multirow{2}{*}{$\begin{array}{l}\text { Child unable to } \\
\text { micturate on } \\
\text { demand } \\
\text { (no.) }\end{array}$} \\
\hline & & & & $\begin{array}{l}\text { Reason not given } \\
\text { (no.) }\end{array}$ & $\begin{array}{l}\text { Child under } \\
\text { medical care } \\
\text { (no.) }\end{array}$ & \\
\hline $\begin{array}{c}4-7 \\
8-11 \\
12-18\end{array}$ & $\begin{array}{r}59 \\
63 \\
165\end{array}$ & $\begin{array}{r}10 \\
2 \\
15\end{array}$ & $\begin{array}{l}14 \\
20 \\
71\end{array}$ & $\begin{array}{l}10 \\
14 \\
59\end{array}$ & $\begin{array}{l}5 \text { (4 UTI) }{ }^{\star} \\
10 \text { (10 UTI) } \\
20 \text { (10 UTI) }\end{array}$ & $\begin{array}{r}20 \\
17 \\
0\end{array}$ \\
\hline Total & $287 \quad 100 \%$ & $27 \quad 9 \cdot 4 \%$ & $105 \quad 36 \cdot 6 \%$ & $83 \quad 28 \cdot 9 \%$ & $35 \quad 12 \cdot 2 \%$ & $37 \quad 12 \cdot 9 \%$ \\
\hline
\end{tabular}

«UTI, urinary tract infection confirmed. 
at the time the school was visited; none was found to have had a urinary tract infection. It is therefore most unlikely that the occurrence of ASB among these 287 children was high enough to have any appreciable effect on the following analysis of the prevalence of ASB.

Results of the screening tests. Of the 13464 girls who were screened, 409 (3.04\%) yielded growth of $10^{5}$ or more organisms per $\mathrm{ml}$ urine in the first specimen. A further $73(0.5 \%)$ yielded between $10^{4}$ and $10^{5}$ organisms other than coagulase-negative staphylococci. The results obtained with the two further specimens that were subsequently obtained from these girls are set out in Table IV. Of the

\section{TABLE IV}

Bacteriology results from the 2 additional specimens from all 482 girls who yielded $>10^{4}$ organisms ${ }^{\star} / \mathrm{ml}$ in their screening test

\begin{tabular}{|c|c|c|c|c|}
\hline \multicolumn{3}{|c|}{ Viable count of bacteria/ml urine } & \multicolumn{2}{|c|}{ Girls } \\
\hline Screening test & 2nd specimen & 3rd specimen & No. & $\%$ \\
\hline $\begin{array}{l}\geqslant 10^{s} \\
\geqslant 10^{s} \\
\geqslant 10^{s} \\
\geqslant 10^{s} \\
10^{4}-10^{s}\end{array}$ & $\begin{array}{c}10^{4}-10^{5} \\
<10^{4} \\
10^{4}-10^{5} \\
<10^{4} \\
<10^{4}\end{array}$ & $\begin{array}{c}10^{4}-10^{5} \\
10^{4}-10^{5} \\
<10^{4} \\
<10^{4} \\
<10^{4}\end{array}$ & $\begin{array}{r}9 \\
11 \\
19 \\
106 \\
69\end{array}$ & $\begin{array}{r}1 \cdot 9 \\
2 \cdot 3 \\
3 \cdot 9 \\
22 \cdot 0 \\
14 \cdot 3\end{array}$ \\
\hline $\begin{array}{l}\begin{array}{l}\text { Girls classi } \\
10^{4}-10^{s}\end{array} \\
\geqslant 10^{5} \\
\geqslant 10^{s} \\
\geqslant 10^{s}\end{array}$ & $\begin{array}{c}-\quad-1 \text { as not having } \\
>10^{\mathrm{s}} \\
10^{4-10^{\mathrm{s}}} \\
>10^{\mathrm{s}} \\
>10^{\mathrm{s}}\end{array}$ & $\begin{array}{c}-b a c t e r i u r i a \\
>10^{5} \\
>10^{5} \\
10^{4}-10^{5} \\
>10^{5}\end{array}$ & $\begin{array}{r}214 \\
- \\
11 \\
8 \\
245\end{array}$ & $\begin{array}{r}44 \cdot 4 \\
-0 \cdot 8 \\
2 \cdot 3 \\
1 \cdot 7 \\
50 \cdot 8-\end{array}$ \\
\hline \multicolumn{3}{|c|}{ Girls classified as having bacteriuria } & 268 & $55 \cdot 6$ \\
\hline
\end{tabular}

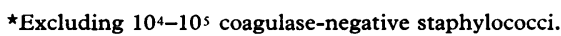

total of $482,214(44 \cdot 4 \%)$ were not regarded as having significant bacteriuria; of these 175 yielded less than $10^{4}$ organisms $/ \mathrm{ml}$ in both specimens, 30 yielded less than $10^{4}$ organisms $/ \mathrm{ml}$ in one specimen and between $10^{4}$ and $10^{5}$ organisms $/ \mathrm{ml}$ in the other, and 9 yielded between $10^{4}$ and $10^{5}$ organisms $/ \mathrm{ml}$ in both. The remaining 268 girls $(55 \cdot 6 \%)$ were confirmed as having significant bacteriuria; 245 yielded more than $10^{5}$ organisms $/ \mathrm{ml}$ in both additional specimens, 19 yielded $10^{5}$ or more organisms in one additional specimen but between $10^{4}$ and $10^{5}$ organisms $/ \mathrm{ml}$ in the other. 4 girls who had between $10^{4}$ and $10^{5}$ organisms $/ \mathrm{ml}$ in their first specimen $\left(4 \times 10^{4}, 6 \times 10^{4}, 8 \times 10^{4}, 9 \times 10^{4}\right.$, respectively) had more than $10^{5}$ organisms $/ \mathrm{ml}$ in both subsequent specimens.

As a check on the sensitivity of the screening method, 1270 girls who were negative on the screening test were tested a second time within a week of the first test. None was found to have bacteriuria.

Of the 268 girls with bacteriuria, 12 had previously had symptomatic urinary tract infection and had been referred to hospital where the diagnosis had been confirmed. This left 256 $(1.9 \%)$ who had not previously been referred to hospital and were regarded as having 'asymptomatic bacteriuria'. The ages of these 256 girls are set out in Table II with the proportion they represent of the number tested at each respective age. The proportion of girls found to have ASB rose from $1.08 \%$ at 4 years to $1 \cdot 27 \%$ at 5 years, to $1 \cdot 55 \%$ at 6 years, and then nearly doubled to $2 \cdot 55 \%$ at 7 years. The prevalence thereafter remained fairly constant at about this figure until 11 years, after which it decreased to an average of $1.6 \%$ from 12 to 18 years. It seems that these prevalences fall naturally into 3 age groups, namely, 4 to 6 years, 7 to 11 years, and 12 to 18 years. The prevalence of $2.5 \%$ for the 7 to 11-year group is significantly higher than the prevalence of $1.4 \%$ for the 4 - to 6-year group, and $1.6 \%$ for the 12 - to 18 -year group ( $P<0.001)$.

Two of the 256 girls who had ASB refused referral to hospital and/or an IVU. Of the remaining 254 who had an IVU, 39 showed renal scarring. Table $\mathrm{V}$ gives the ages of these 39 girls and the proportion

TABLE V

Prevalence of renal scarring in patients with asymptomatic bacteriuria

\begin{tabular}{|c|c|c|c|c|c|c|}
\hline \multirow[t]{2}{*}{$\begin{array}{c}\text { Age } \\
\text { (year) }\end{array}$} & \multirow[t]{2}{*}{$\begin{array}{l}\text { (a) } \\
\text { Girls } \\
\text { screened } \\
\text { (no.) }\end{array}$} & \multicolumn{2}{|c|}{$\begin{array}{l}\text { (b) } \\
\text { Asymptomatic } \\
\text { bacteriuria } \\
\text { present }\end{array}$} & \multicolumn{3}{|c|}{ Renal scarring present } \\
\hline & & No. & $\%$ & No. & $\%(b)$ & $\%$ (a) \\
\hline $\begin{array}{l}4 \\
5 \\
6\end{array}$ & $\begin{array}{r}278 \\
1022 \\
1098\end{array}$ & $\begin{array}{r}3 \\
13 \\
17\end{array}$ & $\begin{array}{l}1 \cdot 08 \\
1 \cdot 27 \\
1.55\end{array}$ & $\left.\begin{array}{l}0 \\
5 \\
1\end{array}\right\}$ & $18 \cdot 18\}$ & 0.25 \\
\hline $\begin{array}{r}7 \\
8 \\
9 \\
10 \\
11\end{array}$ & $\begin{array}{ll}1 & 096 \\
1 & 114 \\
1 & 016 \\
1 & 052 \\
1 & 094\end{array}$ & $\begin{array}{l}27 \\
28 \\
26 \\
28 \\
23\end{array}$ & $\begin{array}{l}2 \cdot 46 \\
2 \cdot 51 \\
2 \cdot 56 \\
2 \cdot 66 \\
2 \cdot 10\end{array}$ & $\begin{array}{l}4 \\
4 \\
5 \\
5 \\
2\end{array}$ & $\begin{array}{r}14 \cdot 81 \\
14 \cdot 29 \\
19 \cdot 23 \\
17 \cdot 86 \\
8 \cdot 70\end{array}$ & $\begin{array}{l}0.36 \\
0.36 \\
0 \cdot 49 \\
0 \cdot 48 \\
0.18\end{array}$ \\
\hline $\begin{array}{l}12 \\
13 \\
14\end{array}$ & $\begin{array}{ll}1 & 362 \\
1 & 320 \\
1 & 245\end{array}$ & $\begin{array}{l}22 \\
21 \\
17\end{array}$ & $\begin{array}{l}1.62 \\
1.59 \\
1.37\end{array}$ & $\begin{array}{l}5 \\
5 \\
2\end{array}$ & $\begin{array}{l}22 \cdot 73 \\
23 \cdot 81 \\
11 \cdot 76\end{array}$ & $\begin{array}{l}0.37 \\
0.38 \\
0 \cdot 16\end{array}$ \\
\hline $\begin{array}{l}15 \\
16 \\
17 \\
18\end{array}$ & $\begin{array}{l}831 \\
510 \\
324 \\
102\end{array}$ & $\begin{array}{r}16 \\
7 \\
5 \\
1\end{array}$ & $\begin{array}{l}1.93 \\
1.37 \\
1.54 \\
0.98\end{array}$ & $\left.\begin{array}{l}1 \\
0 \\
0 \\
0\end{array}\right\}$ & $3 \cdot 45\}$ & 0.06 \\
\hline Total & 13464 & 254 & $1 \cdot 89$ & 39 & $15 \cdot 35$ & 0.29 \\
\hline
\end{tabular}


they form of the total number of girls examined and the number with ASB. The proportion with ASB who had renal scarring was fairly constant in the range of $9 \%$ to $24 \%$ from 4 to 14 years but thereafter was lower at $3.4 \%$. Similarly the prevalence of renal scarring when related to the total population was $0.2 \%$ to $0.5 \%$ between 4 to 14 years and thereafter was lower at $0.06 \%$. However, none of these differences attain statistical significance.

In summary, there was a progressive increase in the prevalence of asymptomatic bacteriuria from $1.08 \%$ at 4 years of age reaching a peak of $2.55 \%$ at 7 years of age. After the age of 11 the prevalence decreased to $1.6 \%$. There was no increase in the prevalence of renal scarring with increasing age.

Leucocyturia. The value of examining urine microscopially for leucocytes as part of a screening programme for bacteriuria is examined in the analysis of the first screening specimen shown in Table VI. Of the 254 patients, 98 had less than 1

\section{TABLE VI}

Presence of leucocytes in the first screening specimen of urine

\begin{tabular}{l|c|c|c}
\hline \multirow{2}{*}{$\begin{array}{c}\text { Leucocytes } / \mathrm{mm}^{3} \\
\text { of urine }\end{array}$} & $\begin{array}{c}\text { Total girls } \\
\text { (no.) }\end{array}$ & \multicolumn{2}{|c}{ Renal scarring present } \\
\cline { 2 - 3 } 0 & 98 & 11 & $\%$ \\
\hline $1-9$ & 27 & 4 & 11 \\
$10-19$ & 17 & 2 & 15 \\
$20-49$ & 28 & 4 & 12 \\
$50-99$ & 18 & 5 & 14 \\
100 & 66 & 13 & 28 \\
\hline Total & 254 & 39 & 100 \\
\hline
\end{tabular}

$\mathrm{WBC} / \mathrm{mm}^{3}$, 27 had 1-9 $\mathrm{WBC} / \mathrm{mm}^{3}$, and 17 had 10-19 WBC/mm $\mathrm{mm}^{3}$. Thus, if the upper level of normal is taken as $19 \mathrm{WBC} / \mathrm{mm}^{3}$, only $112(44 \%)$ of the 254 patients with ASB would have been detected. Altering this definition downwards would not appreciably improve its value in detecting girls with ASB. It might have been expected that examination for leucocyturia would have been of value in detecting those girls with renal scarring. However, of the 39 girls with renal scarring, only 22 (56\%) yielded 20 or more $\mathrm{WBC} / \mathrm{mm}^{3}$.

Infecting organism. For each girl, the organism isolated was the same in all 3 screening tests. Table VII shows the frequency of the different genera. Esch. coli was by far the commonest, being present in
TABLE VII

Bacteria isolated in screening test related to occurrence of renal scarring

\begin{tabular}{|c|c|c|c|c|}
\hline \multirow[t]{2}{*}{ Organism } & \multicolumn{2}{|c|}{$\begin{array}{l}\text { Girls yielding } \\
\text { organism in their } \\
\text { screening test }\end{array}$} & \multicolumn{2}{|c|}{$\begin{array}{c}\text { Renal scarring } \\
\text { present }\end{array}$} \\
\hline & No. (a) & $\%$ & No. & $\%$ (a) \\
\hline $\begin{array}{l}\text { Esch. coli } \\
K l . \text { aerogenes } \\
K l . \text { pneumoniae } \\
\text { Kl. edwardsii } \\
\text { Pr. mirabilis } \\
\text { Alk. dispar } \\
\text { Strep. faecalis } \\
\text { Coagulase + ve } \\
\text { staphylococci } \\
\text { Coagulase - ve } \\
\text { staphylococci } \\
\text { Group B streptococcus }\end{array}$ & $\begin{array}{r}233 \\
7 \\
4 \\
2 \\
3 \\
1 \\
1 \\
1 \\
1 \\
1 \\
1\end{array}$ & $\begin{array}{l}91 \cdot 7 \\
2 \cdot 8 \\
1 \cdot 6 \\
0 \cdot 8 \\
1 \cdot 2 \\
0 \cdot 4 \\
0 \cdot 4 \\
0.4 \\
0.4 \\
0.4\end{array}$ & $\begin{array}{c}33 \\
2 \\
1 \\
2 \\
1 \\
0 \\
0 \\
0 \\
0 \\
0\end{array}$ & $\begin{array}{l}14 \\
38 \\
33\end{array}$ \\
\hline Total & 254 & $100 \cdot 1$ & 39 & 15 \\
\hline
\end{tabular}

$233(91 \cdot 8 \%)$. The second was Klebsiella, present in $13(5 \cdot 1 \%)$.

On examining the 6 further MSUs obtained at hospital, 6 girls were found to have on at least three occasions a second organism present in a viable count of more than $10^{5} / \mathrm{ml}$. One of these, a girl who was infected with $\mathrm{Kl}$. aerogenes had also an anaerobic Streptococcus and the remaining 5 girls who were infected with Esch. coli had Strep. faecalis as their second organism. Two other girls had their initial Esch. coli replaced by another organism during the 6-week assessment period; in one the new organism was Haemophilus influenzae and in the other it was Strep. faecalis.

Table VII also shows that renal scarring was found in $33(14 \%)$ of the 233 girls infected with Esch. coli, and in 5 (38\%) of the 13 infected with Klebsiella, a significant difference $(P<0 \cdot 02)$.

Serum antibody titre. The serum obtained at the time of the IVU was tested against the organism isolated from the urine for the titre of agglutinating antibody. The results are set out in Table VIII separately for patients with and without renal scarring. Of the 172 patients without renal scars, $30(17 \%)$ had titres of $1: 320$ or more compared with $18(47 \%)$ of the 38 with scars $(P<0.001)$.

Social class. The social class of the girls with asymptomatic bacteriuria was compared with the social class of a $10 \%$ random sample of the school population screened and shown not to have bacteriuria. As shown in Table IX there is no demonstrable association between social class and the presence of ASB. 
Titre of agglutinating antibody to the homologous organis

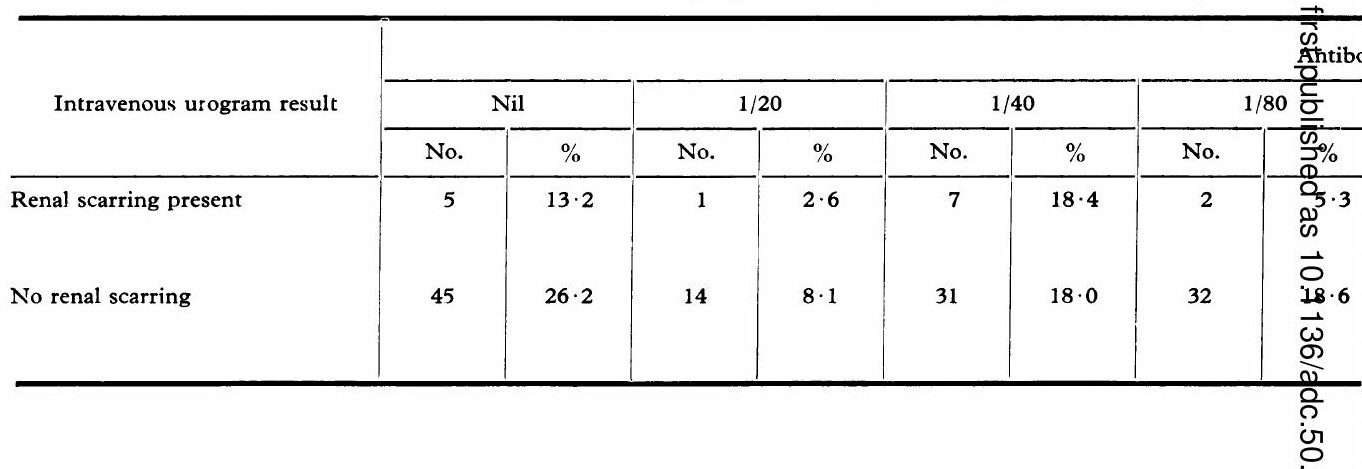

TÄBL

Occurrence of asymptomatic bacterึuri

\begin{tabular}{|c|c|c|c|c|c|c|c|c|}
\hline \multirow[t]{2}{*}{ Social classification } & \multicolumn{2}{|c|}{$\stackrel{\text { I }}{\text { Professional }}$} & \multicolumn{2}{|c|}{$\stackrel{\text { II }}{\text { Executive }}$} & \multicolumn{2}{|c|}{$\underset{\text { Skilled }}{\text { III }}$} & \multicolumn{2}{|c|}{ Semi-skillegd } \\
\hline & No. & $\%$ & No. & $\%$ & No. & $\%$ & No. & \\
\hline $\begin{array}{l}\text { Bacteriuria positive } \\
\text { Bacteriuria negative ( } 10 \% \text { sample) }\end{array}$ & $\begin{array}{r}21 \\
110\end{array}$ & $\begin{array}{l}8 \cdot 2 \\
5 \cdot 6\end{array}$ & $\begin{array}{r}26 \\
253\end{array}$ & $\begin{array}{l}10 \cdot 2 \\
12 \cdot 8\end{array}$ & $\begin{array}{l}130 \\
907\end{array}$ & $\begin{array}{l}50 \cdot 8 \\
45 \cdot 9\end{array}$ & $\begin{array}{r}29 \\
280\end{array}$ & $4 \cdot 3$ \\
\hline
\end{tabular}

Symptoms. The replies from general from these 34 girls were similar to those elicited from practitioners showed that $34(13.4 \%)$ of the 254 the remaining 220 girls, and therefore are not girls referred to hospital had previously been presented separately in Table X. Considering all clinically diagnosed as having a urinary tract the 254 girls, the symptoms most commonly present infection but had not been further investigated. This applied to 2 of the 39 girls who had renal scarring. The clinical symptoms elicited at hospital were urgency $(39 \%)$, abdominal pain $(31 \%)$, and nocturnal enuresis $(30 \%)$. Except for nocturnal enuresis, none of the symptoms had an association

TABLE $\mathrm{X}$

Prevalence of symptoms related to renal scarring and ureteric reflux

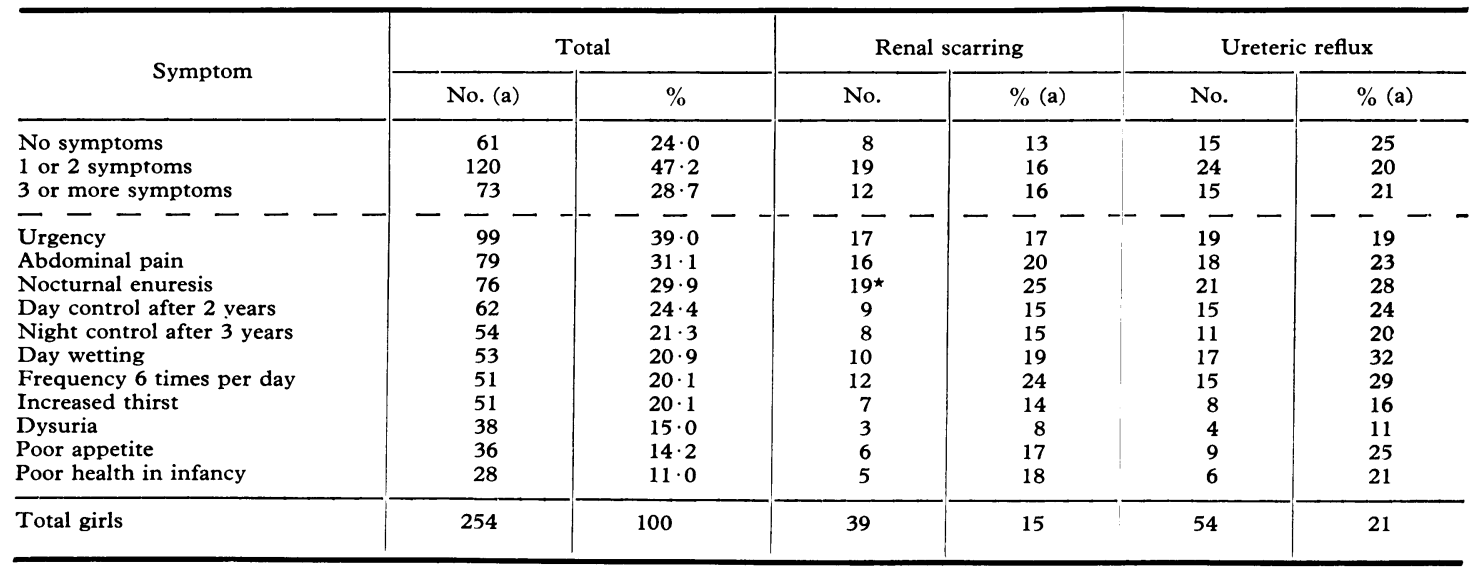

$\star \mathbf{P}<0 \cdot 01$ 
VIII

related to radiological evidence of renal scarring

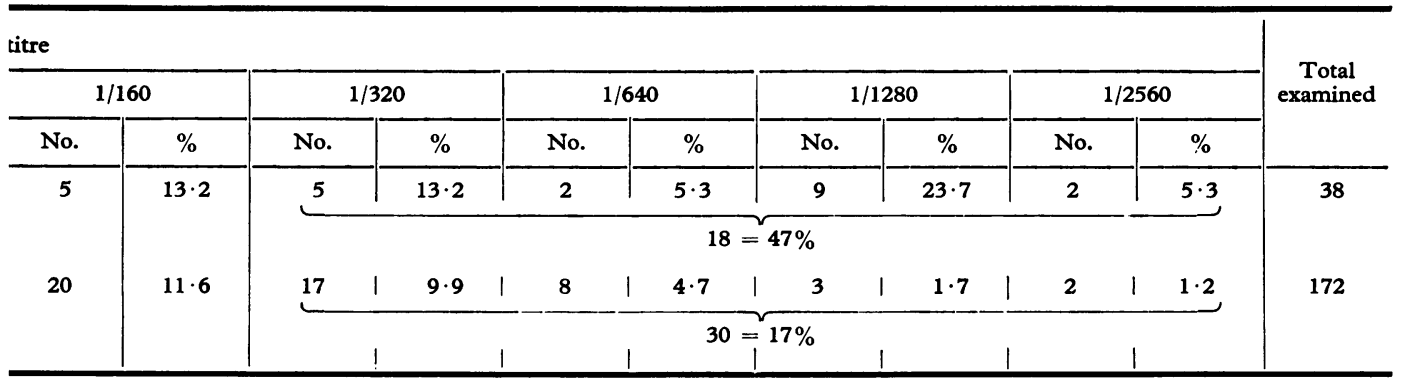

IX

related to social class of father

\begin{tabular}{|c|c|c|c|c|c|c|c|c|c|c|}
\hline \multicolumn{2}{|c|}{$\underset{\text { Unskilled }}{\mathrm{V}}$} & \multicolumn{2}{|c|}{$\begin{array}{c}\text { VI } \\
\text { Permanent sick }\end{array}$} & \multicolumn{2}{|c|}{$\begin{array}{c}\text { VII } \\
\text { Armed Forces }\end{array}$} & \multicolumn{2}{|c|}{$\begin{array}{c}\text { VIII } \\
\text { Unemployed }\end{array}$} & \multicolumn{2}{|c|}{$\underset{\text { Not known }}{\text { IX }}$} & \multirow{2}{*}{ Total } \\
\hline No. & $\%$ & No. & $\%$ & No. & $\%$ & No. & $\%$ & No. & $\%$ & \\
\hline $\begin{array}{r}28 \\
208\end{array}$ & $\begin{array}{l}10.9 \\
10.5\end{array}$ & $\begin{array}{l}0 \\
5\end{array}$ & $\begin{array}{l}0 \cdot 0 \\
0 \cdot 3\end{array}$ & $\begin{array}{r}5 \\
16\end{array}$ & $\begin{array}{l}2 \cdot 0 \\
0 \cdot 8\end{array}$ & $\begin{array}{l}17 \\
26\end{array}$ & $\begin{array}{l}6 \cdot 6 \\
1 \cdot 3\end{array}$ & $\begin{array}{r}0 \\
172\end{array}$ & $\begin{array}{l}0.0 \\
8.7\end{array}$ & $\begin{array}{r}256 \\
1977\end{array}$ \\
\hline
\end{tabular}

with the presence of renal scarring or ureteric reflux at the $1 \%$ level. Renal scarring was as common in the 61 girls who had no symptoms as in the 193 girls who had one or more symptoms.

Signs. The findings of the clinical examination done at hospital are set out in Table XI and related to the radiological findings. There were more tall and heavy girls than would have been expected from the centile charts of Tanner, Whitehouse, and Takaishi (1966), and they were significantly more frequently from social classes III, IV, and V. However as shown in Table IX, there was no excess in the girls with ASB of any social class. There was

TABLE XI

Clinical assessment related to the radiological findings

\begin{tabular}{|c|c|c|c|c|c|c|c|c|}
\hline \multirow{3}{*}{ Clinical assessment } & & & \multicolumn{6}{|c|}{ Radiological findings } \\
\hline & \multicolumn{2}{|c|}{ Total } & \multicolumn{2}{|c|}{$\begin{array}{c}\text { Renal scarring } \\
\text { present }\end{array}$} & \multicolumn{2}{|c|}{$\begin{array}{l}\text { Ureteric reflux } \\
\text { present }\end{array}$} & \multicolumn{2}{|c|}{$\begin{array}{c}\text { Abnormal bladder } \\
\text { wall }\end{array}$} \\
\hline & No. (a) & $\%$ & No. & $\%(a)$ & No. & $\%$ (a) & No. & $\%$ (a) \\
\hline $\begin{array}{l}\text { Weight } \\
<10 \text { th centile } \\
>90 \text { th centile }\end{array}$ & $\begin{array}{l}41 \\
64\end{array}$ & $\begin{array}{l}16 \cdot 1 \\
25 \cdot 2\end{array}$ & $\begin{array}{r}5 \\
12\end{array}$ & $\begin{array}{l}12 \\
19\end{array}$ & $\begin{array}{c}4 \\
20^{\star}\end{array}$ & $\begin{array}{l}10 \\
31\end{array}$ & $\begin{array}{r}8 \\
12\end{array}$ & $\begin{array}{l}20 \\
19\end{array}$ \\
\hline $\begin{array}{l}\text { Height } \\
<10 \text { th centile } \\
>90 \text { th centile }\end{array}$ & $\begin{array}{l}16 \\
57\end{array}$ & $\begin{array}{r}6 \cdot 3 \\
22 \cdot 4\end{array}$ & $\begin{array}{r}3 \\
11\end{array}$ & $\begin{array}{l}19 \\
19\end{array}$ & $\begin{array}{c}4 \\
19+\end{array}$ & $\begin{array}{l}25 \\
33\end{array}$ & $\begin{array}{l}1 \\
8\end{array}$ & $\begin{array}{r}6 \\
14\end{array}$ \\
\hline $\begin{array}{l}\text { Blood pressure } \\
>90 \mathrm{mmHg} \text { diastolic }\end{array}$ & 6 & $2 \cdot 4$ & 2 & 33 & 2 & 33 & 0 & 0 \\
\hline Palpable kidney & 4 & 1.6 & 2 & 50 & 1 & 25 & 0 & 0 \\
\hline Palpable bladder & 11 & $4 \cdot 3$ & 2 & 18 & 3 & 27 & 2 & 18 \\
\hline Vulval inflammation & 17 & $6 \cdot 7$ & 2 & 12 & 4 & 24 & 1 & 6 \\
\hline Albuminuria & 32 & $12 \cdot 6$ & 7 & 22 & 6 & 19 & 7 & 22 \\
\hline $\begin{array}{l}\text { Leucocyturia }>20 \text { cells } / \mathrm{mm}^{3} \text { in } 3 \text { or } \\
\text { more specimens }\end{array}$ & 126 & $49 \cdot 6$ & $28 t$ & 22 & $36 t$ & 29 & 22 & 17 \\
\hline
\end{tabular}

$\star P<0.05$.

$+\mathrm{P}<0.01$. 
little yield from clinical examination; only 4 girls ( $1.6 \%)$ had palpable kidneys, of whom 2 had renal scarring; bladders were palpable in $11(4 \cdot 3 \%)$, and 5 $(2.0 \%)$ had a diastolic blood pressure of $90 \mathrm{mmHg}$, and one had a diastolic pressure of $120 \mathrm{mmHg}$. Only this girl had confirmed hypertension, and she also had papilloedema, raised blood urea and serum creatinine, and gross bilateral renal scarring. Her only symptoms were poor appetite and excessive thirst.

Except for ureteric reflux being more common in the girls above the 90th centile in weight or height, none of the clinical findings correlated with the presence of radiological abnormalities.

Leucocyturia of 20 or more cells per $\mathrm{mm}^{3}$ was found in three or more specimens of urine in 126 $(49.6 \%)$ of the 254 girls, and was associated with the presence of renal scarring and ureteric reflux $(P<0 \cdot 01)$.

Of the 254 girls, $25(9 \cdot 8 \%)$ failed to yield any further positive cultures when they attended hospital though each had 6 MSUs examined. A further $16(6 \cdot 3 \%)$ yielded one or 2 culture-positive MSUs and then became negative on culture. 3 of these 41 girls had renal scarring but none had received any antibacterial chemotherapy.

Radiological findings. The prevalence of the radiological abnormalities is shown in Table XII. Scarring was found in one or other kidney in 39 $(15 \%)$ and ureteric reflux in $54(21 \%) .18$ had both scars and reflux, a significant association $(P<0.001)$. Scarring also showed an association with duplication (7 girls, $P<0.01)$, hydroureter $(5$ girls, $P<0.001$ ), and a single saccule in the bladder (5 girls, $P<0.001$ ). Generalized irregularities of the bladder margin were orginally analysed into 3 categories, namely, trabeculation, equivocal trabeculation, and multiple small saccules. There was no significant association between these 3 categories and either scarring or reflux. They have therefore all been listed as trabeculation with the understanding that this radiological diagnosis would not necessarily correspond with a cystoscopic diagnosis of trabeculation.

Apart from scarring, the only radiological findings which showed a significant association with reflux were hydroureter ( 6 girls, $P<0.001)$ and duplication (9 girls, $P<0.001)$.

Duplication was originally analysed into 3 categories: bifid renal pelvis (9 girls, bilateral in 3), joined double ureters (none), and double ureters without evidence of their joining (7 girls, bilateral in 3). However, analysing these separately, none showed significant associations and for this reason the numbers are combined to show an association with both scarring and reflux.

No surprising association was found between abnormalities of the onset of micturition, as noted at the time of cystogram, or of the volume at which the desire to void appeared and any of the other radiological features. Trabeculation was found more frequently in girls with urgency and smaller bladder capacities. As would be expected, urgency was found more frequently with a small bladder volume, and delayed or incomplete micturition occurred more frequently with a large bladder volume.

The relation between the severity of scarring and the presence or absence of reflux is shown in Table XIII. This shows that the greater the severity of scarring, the more likely it is to be associated with reflux. It shows also that when the scarring is bilateral it is more likely to be associated with reflux and more likely to be severe.

There was no association between the severity of the renal scarring and the age of the child. Thus, scarring was severe in 6 of the 26 children aged 11

TABLE XII

Radiological findings associated with scarring and reflux

\begin{tabular}{|c|c|c|c|c|c|}
\hline Investigation (a) & Abnormality & No. & $\%$ (a) & $\begin{array}{l}\text { Association with } \\
\text { scarring }\end{array}$ & $\begin{array}{l}\text { Association with } \\
\text { reflux on cystogram }\end{array}$ \\
\hline $\begin{array}{l}\text { Intravenous urogram } \\
254 \text { examined }\end{array}$ & $\begin{array}{l}\text { Kidney scars } \\
\text { Duplication } \\
\text { Pelviureteric obstruction } \\
\text { Localized caliectasis } \\
\text { Hydroureter }\end{array}$ & $\begin{array}{r}39 \\
16 \\
1 \\
1 \\
9\end{array}$ & $\begin{array}{r}15 \cdot 4 \\
6 \cdot 3 \\
0 \cdot 4 \\
0 \cdot 4 \\
3 \cdot 5\end{array}$ & $\begin{array}{c}\text { All } \\
7 \\
-\end{array}$ & $\begin{array}{r}18 \\
- \\
6\end{array}$ \\
\hline $\begin{array}{l}\text { Cystogram } \\
252 \text { examined }\end{array}$ & $\begin{array}{l}\text { Reflux } \\
\text { Trabeculation } \\
\text { Single saccule }\end{array}$ & $\begin{array}{r}54 \\
40 \\
5\end{array}$ & $\begin{array}{r}21 \cdot 4 \\
15 \cdot 9 \\
2 \cdot 0\end{array}$ & $\begin{array}{r}18 \\
7 \\
5\end{array}$ & $\begin{array}{r}\text { All } \\
10 \\
2\end{array}$ \\
\hline
\end{tabular}


TABLE XIII

Comparison of the severity of scarring in 21 girls without and 18 girls with associated ureteric reflux

\begin{tabular}{|c|c|c|c|c|c|}
\hline \multirow{2}{*}{ Severity of scars } & \multicolumn{2}{|c|}{ Scars only } & \multicolumn{2}{|c|}{ Scars plus reflux } & \multirow{2}{*}{ Total } \\
\hline & Unilateral & Bilateral* & Unilateral scars & Bilateral scars * & \\
\hline $\begin{array}{l}\text { Mild } \\
\text { Moderate } \\
\text { Severe }\end{array}$ & $\begin{array}{r}14 \\
6 \\
0\end{array}$ & $\begin{array}{l}0 \\
1 \\
0\end{array}$ & $\begin{array}{l}3 \\
5 \\
2\end{array}$ & $\begin{array}{l}1 \\
2 \\
5\end{array}$ & $\begin{array}{r}18 \\
14 \\
7\end{array}$ \\
\hline Total & 20 & 1 & 10 & 8 & 39 \\
\hline
\end{tabular}

*The severity of bilateral scarring is assessed as the severity of the more affected kidney.

years or less, compared with 1 of 13 aged 12 years or more. The corresponding figures for moderate scarring was 9 of 26 and 5 of 13 . Table XIV shows that when reflux is of a more severe grade or bilateral it is more likely to be associated with scarring.

The size of the two kidneys in each patient is compared in Table XV, which shows that the left kidney is more frequently longer than the right kidney. This difference is apparent for both the scarred kidneys and the otherwise normal kidneys and is therefore not caused by a greater prevalence of scarring on the right.

\section{Discussion}

In the present study bacteriuria has been defined as the presence of $10^{5}$ or more organisms per ml urine (Kass, 1956). The highly consistent results obtained in the series of 3 tests on each girl who yielded a positive result in the screening test has confirmed the validity of this definition. Thus on retesting, counts between $10^{4}$ and $10^{5}$ organisms $/ \mathrm{ml}$ were obtained in only 32 girls-in 23 in only one of the two subsequent tests and in 9 in both tests. The 23 girls were classified as having significant bacteriuria and this was confirmed by subsequent examination at hospital. The 9 girls were regarded as not having significant bacteriuria and this has been confirmed by follow-up investigations. Accepting the correctness of the decisions made in classifying these girls, the sensitivity and specificity of the screening method used in this study can be expressed from the results given in Table IV using standard formulae (Wilson and Jungner, 1968). Thus with the definition of bacteriuria as $>10^{5}$ organisms, the sensitivity of the screening test was $98 \cdot 5 \%$ and its specificity was $98 \cdot 90 \%$. Using the

TABLE XIV

Comparison of the grade of reflux in 36 girls without and 18 girls with associated scarring

\begin{tabular}{l|c|c|c|c|c}
\hline \multirow{2}{*}{ Grade of reflux } & \multicolumn{2}{|c|}{ Reflux only } & \multicolumn{2}{|c}{ Reflux plus scars } & Total \\
\cline { 2 - 5 } & Unilateral & Bilateral & Unilateral reflux & Bilateral reflux & \\
\hline Grade 1 & 19 & 6 & 2 & 2 & 29 \\
Grades 2-4 & 5 & 6 & 6 & 8 & 25 \\
\hline Total & 24 & 12 & 8 & 10 & 54 \\
\hline
\end{tabular}

* Grade of bilateral reflux is assessed as the grade on the more affected side.

Note: There is an association $(P<0.01)$ between the severity of reflux and the finding of reflux plus scars in the cases with unilateral reflux.

TABLE XV

Comparison of the difference in size between the kidneys on 242 girls in whom measurements were possible

\begin{tabular}{l|c|c|c|c|c|c|c|c|c}
\hline & \multicolumn{2}{|c|}{ Left larger (mm) } & $\begin{array}{c}\text { Equal size } \\
\text { kidney }\end{array}$ & \multicolumn{3}{|c|}{ Right larger (mm) } \\
\cline { 2 - 7 } & $30-39$ & $20-29$ & $10-19$ & $>0-9$ & & $>0-9$ & $10-19$ & $20-29$ & $30-39$ \\
\hline $\begin{array}{l}\text { Scarred kidneys } \\
\text { Normal kidneys }\end{array}$ & 2 & 4 & 14 & 29 & 12 & 12 & 5 & 1 & 2 \\
\hline Total & 0 & 0 & 22 & 74 & 29 & 33 & 3 & 0 & 0 \\
\hline
\end{tabular}


$>10^{4}$ definition (but excluding coagulase-negative staphylococci in counts of $10^{4}$ to $10^{5}$ ) the sensitivity was $100 \%$ and its specificity was $98.38 \%$. The specificity of the method used here with $>10^{5}$ organisms $/ \mathrm{ml}$ definition (98.90\%) compares favourably with that of $86 \cdot 87 \%$ obtained by Kunin et al. (1962), $97.92 \%$ by Asscher et al. (1973) in Cardiff and $98.24 \%$ in Oxford, $96.38 \%$ obtained by Savage et al. (1973), and $97 \cdot 3 \%$ by Brundtland and Hovig (1973).

Our prevalence of ASB in girls aged 4 to 6 years was $1.4 \%$, which is similar to the $1.6 \%$ found by Savage et al. (1973) for girls aged 5 to 6 years. However, Kunin et al. (1962) detected a lower prevalence rate of $0.7 \%$ in girls aged 5 to 9 years in Virginia, U.S.A., and Asscher et al. (1973) found the prevalence rate for girls aged 5 to 7 years was $1 \cdot 2 \%$ in Cardiff and $2.4 \%$ in Oxford. Of these, only Kunin's result is significantly different from ours $(P<0.05)$. Considering girls aged 7 to 11 years, we found ASB in $2.5 \%$ whereas Asscher et al. (1973) found a prevalence of $1.8 \%$ in Cardiff and $1.4 \%$ in Oxford. These results are significantly lower than ours $(P<0.01)$, but the numbers tested were small, particularly in the Oxford series and the proportions of each age tested were not the same.

Symptoms of urinary tract disease were present in $76 \%$ of the 254 girls classified as having ASB, a finding which is nearly identical to the $75 \%$ found by Savage et al. (1973) and is similar to the $66 \%$ found by Kunin (1970). Thus from all three surveys it is clear that most of the children detected were not truly asymptomatic. Perhaps either 'covert bacteriuria' suggested by Savage et al. (1973) or 'undiagnosed bacteriuria' would be a more appropriate term. However, 'asymptomatic bacteriuria' by common usage does not imply that the patient is free from symptoms, but that any that have been present have not led to the patient receiving medical care, presumably because they are usually mild and nonspecific. For example, nocturnal enuresis was present in $30 \%$ of the total girls with bacteriuria and in as many as $48 \%$ of the 5 and 6 year olds. However, nocturnal enuresis is very common in children and according to Stansfeld (1973) even a girl who wets her bed nearly every night has only a $10 \%$ chance of having a urinary tract infection.

It is interesting that there was little correlation between the presence of symptoms and the finding of renal scarring or ureteric reflux. Thus symptoms are of little value in deciding on the need for radiological examination. Similarly, with the exception of leucocyturia, physical examination was of little value in selecting those with renal scarring.
We cannot explain the association between children above the 90th centile in weight or height and an increased frequency of ureteric reflux.

The present study like those of Kunin et al. (1962) and Stansfeld (1966) did not find an association between ASB and social class, such as that found by Savage et al. (1973) in Dundee. This may be due to differences between the populations.

The presence of scarred kidneys in $15 \%$ of girls with ASB is similar to that found in other studies. Savage et al. (1973) found scarred kidneys in 13.5\% of 845 -year-old school entrants without a previous history of known urinary tract infection; Asscher et al. (1973) found $20 \%$ in 5- to 11-year-old girls in Oxford and Cardiff, and Kunin et al. (1962) found $16 \%$ in Virginian schoolgirls. Williams et al. (1968) found scarred kidneys in $17 \%$ of pregnant women with ASB and Sussman et al. (1969) found that $13 \%$ of nonpregnant adult women with ASB had renal scars. Smellie et al. (1964) found scarred kidneys in only $16 \%$ of children presenting at hospital with symptomatic urinary tract infection. Looking at all these series, what is striking is the similarity of the prevalences of scarring in females with bacteriuria, varying from $13 \%$ to $20 \%$ regardless of the method of clinical presentation.

It has been suggested (Sherwood, 1973) that only gross vesicoureteric reflux leads to renal scarring. In the present series the more severe grades of reflux were more often associated with scars than the lesser grades, but scarring was still found in children with reflux which did not reach as high as the kidney. Furthermore, 21 girls with scars had no reflux. It is of course possible that reflux was either present or was more severe when the scars were produced or that in these cases the scars had some other aetiology.

It has also been suggested that the pressure at which reflux occurs may be important in the development of scarring (Hodge, 1967). We did not have the opportunity to monitor bladder pressure but we found no association between scarring of the kidneys and the timing of the reflux (whether during filling or micturition, or whether persistent or continuous) or the bladder volume at which the desire to void appeared.

Duplication was found more frequently in girls with scarring or reflux than in those who did not have these abnormalities. It is often thought that this association is the result of reflux into a completely duplicated ureter (Hartman and Hodson, 1969), but this was not the explanation in the present series as most had simply a bifid renal pelvis. Possibly retrograde peristalsis from one moiety to the other, as described by Campbell (1967) is 
important. This could lead to poor drainage from the renal pelvis with impairment of the antibacterial mechanism and consequently the persistence of infection which could then cause reflux from the bladder.

Irregularities of the bladder margin were found frequently. We have used the term trabeculation for an irregularity which was present in a film of the distended noncontracting bladder. Savage et al. (1973) commented that they found that trabeculation was always seen at cystoscopy when present radiologically. Cystoscopy was not done routinely in our series and we have not had the opportunity to relate radiological to cystoscopic findings. We would expect that in some patients trabeculation would be caused by cystitis with mucosal oedema (Hertz, 1973). Trabeculation or sacculation was found in $18 \%$ of the Newcastle children and $21 \%$ of the Dundee children. There were 5 girls with single saccules close to the ureteric orifice, which are probably the diverticular described by Hutch (1961). All 5 had kidney scars but only 2 had reflux. We have excluded 11 girls who were found to have saccules only on the films taken during micturition, since these are probably of no pathological importance (Edwards, 1964). There was no correlation between finding these saccules on micturition and either reflux or kidney scars.

The final observation arising from the radiology, that the left kidney was more frequently the longer, confirms the finding of Moëll (1956). This fact leads to the conclusion that a difference in size between the 2 kidneys is more likely to be important if the left is the smaller.

The reason for designing this survey to include children from 4 to 18 years was to see if the prevalence of ASB or renal scarring increased with age. We have found that the prevalence of ASB did increase up to the age of 11 years, but thereafter it decreased. It could be argued that as the children grew older, some changed from covert to overt disease, particularly those with renal scarring, and thus by our definition were excluded from the population who were classified as having ASB. However, there is no support for this from the age distribution of the 12 girls found to have bacteriuria but known to have been referred to hospital previously (Table II) and the 24 girls who were not examined because they were already known to be under medical treatment for urinary tract infection (Table III). Of these 36 girls, 24 were aged 11 years or less and 12 were aged 12 years or more, and they form $15 \%$ and $13 \%$, respectively, of the numbers found to have ASB in these two age groups. It therefore may be concluded that there was a genuine decrease in the prevalence of ASB after the age of 11 years. There was no evidence of an increase in the prevalence of renal scarring with age in those children with ASB. This conclusion is not influenced by the exclusion of the previously known or nonexamined children from this analysis since only 6 of them had renal scarring. Finally, there was no evidence that the severity of the renal scarring increased with age. Thus, there is no evidence from this study to support the suggestion that ASB in childhood leads to progressive renal damage. The only justification for prescriptive screening for ASB in schoolgirls, therefore, can be to detect the $15 \%$ of children with ASB who have renal scarring. In this respect it must be appreciated that they form $0.29 \%$ of the schoolgirl population, and in only a sixth of these, namely, $0.05 \%$ of the population, was the degree of renal scarring severe. A decision to screen for renal scarring can be taken only after due consideration is given to the problems of the treatment and management of the children with ASB without renal scarring, since there is no way to detect the former without the latter. Savage et al. (1973) in a thorough discussion of these problems concluded that screening should not be recommended at present. The results of the present study support this conclusion. However, our study was a simple cross-sectional survey with its inherent limitations and possible sources of bias. We therefore are following this with a longitudinal study on the girls found to have ASB in order to obtain more definite information on the natural history of ASB and the extent to which this may be modified by treatment. The findings of this prospective study will be the subject of further communications.

We are grateful to Mrs. J. E. S. Linkleter, Mrs. B. Whitehead, Mrs. O. Murcott, and Mrs. M. Turner for their enthusiastic assistance without which this study could not have been undertaken.

The project was supported by a research grant from the Department of Health and Social Security.

\section{REFERENCES}

Asscher, A. W., McLachlan, M. S. F., Verrier Jones, R., Meller, S. Sussman, M., Harrison, S., Johnston, H. H., Sleight, G., and Fletcher, E. W. (1973). Screening for asymptomatic urinarytract infection in schoolgirls. Lancet, $2,1$.

Brundtland, G. H., and Hovig, B. (1973). Screening for bacteriuria in schoolgirls. American fournal of Epidemiology, 97, 246.

Campbell, J. E. (1967). Ureteral peristalsis in duplex renal collecting systems. American fournal of Roentgenology, Radium Therapy and Nuclear Medicine, 99, 577.

Cowan, S. T., and Steel, K. J. (1965). Manual for the Identification of Medical Bacteria. Cambridge University Press, London.

Edwards, D. (1964). Cystourethrography. In Recent Advances in Radiology, 4th ed., p. 182. Ed. by T. Lodge. Churchill, London. 
Hartman, G. W., and Hodson, C. J., (1969). The duplex kidney and related abnormalities. Clinica! Radiology, 20, 387.

Hertz, M. (1973). Cystourethrography. A Radiographic Atlas, p. 95. Excerpta Medica, Amsterdam.

Hodge, K. E. (1967). Combined synchronous voiding cinecystourethrography and cystometry in the investigation of vesico-ureteral reflux in children. Fournal of the Canadian Association of Radiologists, 18, 342.

Hutch, J. A. (1961). Saccule formation at the ureterovesical junction in smooth walled bladders. Fournal of Urology, 86, 390.

Kass, E. H. (1956). Asymptomatic infections of the urinary tract. Transactions of the Association of American Physicians, 69, 56.

Kunin, C. M. (1970). A ten-year study of bacteriuria in schoolgirls : final report of bacteriologic, urologic, and epidemologic findings. Fournal of Infectious Diseases, 122, 382.

Kunin, C. M., Zacha, E., and Paquin, A. J. (1962). Urinary-tract infections in school children: Prevalence of bacteriuria and associated urologic findings. New England fournal of Medicine, 266, 1287.

Mackey, J. P., and Sandys, G. H. (1965). Laboratory diagnosis of the urinary tract in general practice by means of a dip-inoculum transport medium. British Medical fournal, 2, 1286.

Meadow, S. R., White, R. H. R., and Johnston, N. M. (1969). Prevalence of symptomless urinary tract disease in Birmingham schoolchildren. Pyuria and bacteriuria. British Medical fournal, 3, 81 .

Miles, A. A., Misra, S. S., and Irwin, J. O. (1938). The estimation of the bactericidal power of the blood. Fournal of Hygiene, 38, 732.

Moëll, H. (1956). Size of normal kidneys. Acta Radiologica, 46, 640 .

Percival, A., Brumfitt, W., and Louvois, J. De (1964). Serumantibody levels as an indication of clinically inapparent pyelonephritis. Lancet, 2, 1027.
Savage, D. C. L., Wilson, M. I., McHardy, M., Dewar, D. A. E., and Fee, W. M. (1973). Covert bacteriuria of childhood. A clinical and epidemiological study. Archives of Disease in Childhood, 48, 8.

Sherwood, T. (1973). Ureteric reflux 1973: chronic pyelonephritis v. reflux nephropathy. British fournal of Radiology, 46, 653.

Smellie, J. M., Hodson, C. J., Edwards, D., and Normand, I. C. S. (1964). Clinical and radiological features of urinary infection in childhood. British Medical fournal, 2, 1222.

Stansfeld, J. M. (1966). Clinical observations relating to incidence and aetiology of urinary-tract infections in children. British Medical fournal, 1, 631.

Stansfeld, J. M. (1973). Enuresis and urinary tract infection. In Bladder Control and Enuresis, p. 103. Ed. by I. Kolvin, R. C. Mac Keith, and S. R. Meadow. Heinemann, London.

Sussman, M., Asscher, A. W., Waters, W. E., Evans, J. A. S., Campbell, H., Evans, K. T., and Williams, J. E. (1969). Asymptomatic significant bacteriuria in the non-pregnant woman. British Medical fournal, 1, 799.

Tanner, J. M., Whitehouse, R. H., and Takaishi, M. (1966). Standards from birth to maturity for height, weight, height velocity, and weight velocity: British children 1965. Archives of Disease in Childhood, 41, 454, 613.

Williams, G. L., Davies, D. K. L., Evans, K. T., and Williams, J. E. (1968). Vesico-ureteric reflux in patients with bacteriuria in pregnancy. Lancet, 2, 1202.

Wilson, J. M. G., and Jungner, G. (1968). Principles and Practice of Screening for Disease, p. 22. World Health Organization, Geneva.

Correspondence to Dr. J. B. Selkon, Bacteriology Department, Newcastle General Hospital, Westgate Road, Newcastle upon Tyne NE4 6BE. 